\title{
Clove (Eugenia caryophyllus) essential oil in diets for Nile tilapia (Oreochromis niloticus) improves fillet quality
}

\author{
Cesar SARY ${ }^{1 *}$ (D), Fabiana CARBONERA ${ }^{1}$, Ana Carolina Pelaes VITAL ${ }^{1}$, Ana GUERRERO ${ }^{2}$, Vanessa \\ LEWANDOWSKI $^{3}$, Jesuí Vergílio VISENTAINER ${ }^{1}$, Ivanor Nunes do PRADO $^{1}$, Ricardo Pereira RIBEIRO
}

\begin{abstract}
This study evaluated the effect of including clove essential oil (EOcl) in Nile tilapia diets on animal performance and antioxidant power, lipid oxidation, gene expression, texture, $\mathrm{pH}$, color and sensory analysis in fillets. Three levels of EOcl in the diets were evaluated $(0.70,1.05$ and $1.40 \mathrm{~g} / \mathrm{kg})$, provided over three periods before slaughtering the animals $(15,45$ and 60 days). The antioxidant power in the diets increased after including EOcl. There was an interaction effect between the level and period of inclusion of EOcl on the antioxidant power and lipid oxidation of fillets stored up to 14 days after slaughter. Lipid oxidation was reduced by $43.3 \%$ compared with the control group. EOcl inclusion in the diet, regardless of level and period, improved texture and promote less gene expression of catalase and glutathione synthetase. This demonstrates that the antioxidant in the tilapia diet acts against the oxidative stress process. Considering the results for the interactions and parameters evaluated, including $1.05 \mathrm{~g} / \mathrm{kg}$ of clove essential oil in the rations for 15 days before slaughter is indicated because it contributes to a higher fillet quality.
\end{abstract}

Keywords: antioxidant power; fish performance; gene expression; lipid oxidation.

Practical Application: The inclusion of essential clove oil in the Nile tilapia diet, 15 days before slaughter can be applied in the industry as a way to improve the quality of the fillet.

\section{Introduction}

Nile tilapia (Oreochromis niloticus), after carps, is the most farmed fish in the world, and represented $8.3 \%$ of world fish production in 2018 (Food and Agriculture Organization, 2020). Fillet is its main commercial product, which has excellent nutritional and sensorial characteristics, with proteins of high biological value and lipid fractions with polyunsaturated fatty acids (Visentainer et al., 2005). These acids include eicosapentaenoic acid (EPA, 20:5n-3), which acts in anti-inflammatory processes and docosahexaenoic acid (DHA, 22:6n-3), which has neuroprotective functions (Rapoport et al., 2011).

Lipid oxidation is the first mechanism to decrease the quality of fish meat (Oskoueian et al., 2013), even if stored under ideal temperature conditions (Ahmed et al., 2015). Fish products are particularly sensitive to lipid oxidation because of their high levels of unsaturated fatty acid chains (Hernández et al., 2015). The oxidation of fatty acids generates products, such as malonaldehyde (MDA), which are highly toxic and are related to degenerative processes and different types of diseases (Vieira et al., 2017). These molecules reduces the acceptance of food products by the consumer market because they decrease the nutritional and sensory quality of food (Kumar et al., 2015; Bernardi et al., 2016).

Synthetic antioxidants such as butylated hydroxyanisole (BHA), butylated hydroxytoluene (BHT), propyl gallate (PG) and tertiary butylhydroquinone (TBHQ), are widely used in the food industry to maintain the quality of meat products (Fasseas et al., 2008). As these synthetic compounds can have toxic effects on the organism and with the growing demand for healthy foods, these antioxidants are being replaced by natural products such as plant extracts and essential oils (Oskoueian et al., 2013).

The application of essential oils in the diets of animals or directly on meat products reduces lipid oxidation and improves their sensory characteristic, in addition to being an antioxidant source via food for humans (Jiang \& Xiong, 2016; Van Haute et al., 2016). Immersion solutions and biofilms containing essential oil (EO) applied directly to fish fillets help to control lipid oxidation (Raeisi et al., 2015). This process, however, alters the flavor and aroma of the product, which results in low rates of sensory acceptance (Raeisi et al., 2015; Van Haute et al., 2016).

The profile of fatty acids of fish is easily altered with diet modulation (Carbonera et al., 2014a; Montanher et al., 2016). Clove essential oil (EOcl), obtained by cold pressing Eugenia caryophyllus leaves, presents high antioxidant power attributed to its main compound, eugenol (84.5\%) (Biondo et al., 2017). Therefore, this study evaluated the effect of including three levels of clove essential oil in Nile tilapia diets for 15, 45 and 60 days before slaughter on animal performance, antioxidant power and quality of fillets.

2 Universidad de Zaragoza, Zaragoza, AR, Spain

3 Universidade Federal da Grande Dourado - UFGD, Dourados, MS, Brasil

*Corresponding author: cesar.sjp87@gmail.com 


\section{Materials and methods}

\subsection{Study site and ethical consideration}

The experiment was conducted at the Net Cage Production Demonstration Unit in the Rosana Reservoir, Paraná, Brazil and the laboratory analyses were conducted at Maringá State University (Universidade Estadual de Maringá - UEM), Paraná, Brazil. The project was approved by the institution's Ethics Committee on Animal Use under protocol no. 9976190415.

\subsection{Animals and experimental design}

Fourteen hundred Nile tilapia (Gift/Tilamax strain), initial average body weight of $186.5 \pm 4.9 \mathrm{~g}$, were randomly distributed into 40 flaoating net cages of $1 \mathrm{~m}^{3}$ (35 fish per net cages) with continuous water flow. They were hand-fed four times a day $(8: 00 ; 11: 00 ; 14: 00$ and 17:00 h) until apparent satiation.

The experiment latest 60 days and was comprised of 10 treatments (one control and nine with test diets), each performed in four replicates. The test diets consisted of inclusion of three levels of clove essential oil (EOcl) $(0.70,1.05$ and $1.40 \mathrm{~g} / \mathrm{kg})$ in a commercial diet for three periods (15, 45 and 60 days) before slaughtering the animals. For inclusion, the EOcl was diluted in a 1:5 hydroalcoholic solution and sprayed into extruded feed. In the control treatment, there was no inclusion of EOcl.

At the end of the experiment, a biometry of all fish was performed with the measurement of weight and standard length (from the beginning of the head to the end of the caudal peduncle). For each net cage has calculated the following indicators of fish performance: final weight (FW), final standard length (FL), daily weight gain $[\mathrm{DWG}=$ (final weight-initial weight $) /$ days of experiment], feed conversion [FC $=$ total feed intake/weight gain] and fillet yield [FY $=100 \mathrm{x}$ (fillet weight/final weight)].

\subsection{Sample collection}

At the end of the experimental period, 240 animals were slaughtered, eviscerated and filleted. The fillets (left side) were labeled and transported for analysis: 40 fillets for antioxidant power; 40 for lipid oxidation; 40 for texture, $\mathrm{pH}$ and color (all measured on the same fillets) and 120 for sensory analysis. Muscle samples to analyze gene expression were collected from six animals (right-side fillets) per treatment.

\subsection{Antioxidant power and lipid oxidation}

The samples (diets and fillets) were previously lyophilized in a freeze drier (CHRIST, ALPHA 1-2 LD plus, Germany) at $-52{ }^{\circ} \mathrm{C}$ and $0.060 \mathrm{mbar}$ for $24 \mathrm{~h}$ and passed through an $80-\mathrm{mesh}(177 \mu \mathrm{m})$ sieve to avoid the effect of grain size.

The 2,2-diphenyl-1-picrylhydrazyl (DPPH), ferric reducing ability power (FRAP) and 2,2'-azino-bis-(3-ethylbenzothiazoline6-sulfonic acid) (ABTS) assays were applied following the QUENCHER procedure. The working solutions were prepared as described by Serpen et al. (2012) and ( \pm )-6-hydroxy-2,5,7,8tetramethyl-chroman-2-carboxylic acid (Trolox) was used as the reference standard for converting the inhibition power to antioxidant power.
Lipid oxidation was determined by the thiobarbituric acidreactive substances (TBARs) test as recommended by Vyncke (1970). The fillets were ground and distributed in Styrofoam trays sealed with plastic film and stored in a refrigerated display unit $\left( \pm 4^{\circ} \mathrm{C}\right)$ under a controlled photoperiod (12:12 light:dark). The fillets were milled to accelerate lipid oxidation to verify the EOcl's antioxidant effect. The assays were performed on days 1, 7 and 14 after slaughter, to verify the antioxidant action of the EOcl included in the fish diet on the fillet over time.

For extraction, a solution containing $7.5 \%$ trichloroacetic acid, $0.1 \%$ gallic acid and $0.1 \%$ EDTA was used. Samples $(5.0 \mathrm{~g})$ were homogenized with the solution $(10 \mathrm{~mL})$, then centrifuged at $4000 \mathrm{rpm}\left(4^{\circ} \mathrm{C}\right)$ for $15 \mathrm{~min}$. First, $10 \mathrm{~mL}$ of this solution was used to homogenize $5.0 \mathrm{~g}$ samples and then centrifugation was performed at $4000 \mathrm{rpm}\left(4^{\circ} \mathrm{C}\right)$ for $15 \mathrm{~min}$.

The supernatant was filtered, and $1.5 \mathrm{~mL}$ was mixed $(1: 1 \mathrm{v} / \mathrm{v})$ with $1 \%$ thiobarbituric acid in a test tube, homogenized and placed in a water bath at $100{ }^{\circ} \mathrm{C}$ for $15 \mathrm{~min}$. The spectrophotometric reading was performed at $532 \mathrm{~nm}$ absorbance, and the results were expressed in $\mathrm{mg} / \mathrm{kg}$ of malondialdehyde (MDA).

\subsection{Analysis of $p H$, texture and color}

Fillet analyzes were performed shortly after slaughter. $\mathrm{pH}$ was determined at three points inside the fillets using a $\mathrm{pH}$ meter (Hanna model HI99163). Texture was determined in four samples measuring $1 \times 1 \times 2 \mathrm{~cm}$ obtained from the dorsal region of the fillets and analyzed perpendicularly to the direction of the muscle fibers in a texturometer (TAXT Plus Texture Analyzer) with a Warner-Bratzler shear blade. Color was evaluated at six random points inside the fillets using a colorimeter (Minolta CR-400) with a $10^{\circ}$ viewing angle and a D65 light source. The $L^{*}, a^{*}$ and $b^{*}$ values were expressed per the color system of the Commission Internationale de L'Eclairage (CIElab).

\subsection{Sensory analysis}

$57(47.50 \%)$ men and 63 women $(52.50 \%)$ were randomly selected, totaling 120 panelists, corresponding to the sex ratio and age of the Brazilian population (Table 1). To prepare the samples, the fillets were divided dorsally into 10 pieces, then wrapped with aluminum foil and cooked on a grill (Philco Jumbo Inox Grill, Philco AS, Brazil) preheated to $200^{\circ} \mathrm{C}$ until reaching an internal temperature of $85^{\circ} \mathrm{C}$, as measured using a skewer thermometer (Incoterm LTDA, Brazil). The samples were identified using a three-digit code and kept in an oven at $50{ }^{\circ} \mathrm{C}$ until served. The treatment samples were presented singly in random order. Panelists were provided with water and unsalted top saltine crackers for rising the palate between samples. They assessed acceptability

Table 1. Sex ratio and age of panelists in sensory analysis.

\begin{tabular}{cccc}
\hline $\begin{array}{c}\text { Age group } \\
\text { (years) }\end{array}$ & Men & Women & $\begin{array}{c}\text { Representativeness } \\
\text { of age group (\%) }\end{array}$ \\
\hline$<24(\%)$ & 42.11 & 44.44 & 43.33 \\
$25-39(\%)$ & 26.32 & 33.33 & 30.00 \\
$40-54(\%)$ & 12.28 & 9.52 & 10.83 \\
$>54(\%)$ & 19.30 & 12.70 & 15.83 \\
Total (\%) & 47.50 & 52.50 & 100 \\
\hline
\end{tabular}


of the aroma, texture, flavor and overall acceptance attributes using a 9-point scale. The intermediate score (5) was excluded from the scale as recommended by Font-i-Furnols et al. (2008).

\subsection{Gene expression analysis}

To evaluate the catalase (CAT), glutathione peroxidase (GPX) and glutathione synthetase (GSS) gene expressions, approximately $2 \mathrm{~g}$ of muscle was collected and stored in RNA Later (Invitrogen, Carlsbad, CA, USA) at $-20^{\circ} \mathrm{C}$. All reagents were from Invitrogen, and the procedure was performed per the manufacturer's instructions (Invitrogen, Carlsbad, CA, USA).

The primers were designed per the sequences deposited at NCBI (National Center for Biotechnology Information, 2021) for the species, using the IDT (Integrated DNA Technologies, 2021). The $\beta$-actin gene (XM_003455949) was used as the endogenous control with the primer developed by Yang et al. (2013).

SYBR $^{\circ}$ GREEN PCR Master Mix fluorescence dye (Applied Biosystems, Foster City, CA, USA) was used for the qRT-PCR reactions. The reactions were conducted in strips in a StepOne Plus device (Applied Biosystems). The 2- $\Delta \mathrm{CT}$ method was used for the relative quantification analyses, and the data were expressed in arbitrary units (AU).

\subsection{Statistical analysis}

The antioxidant power data of the diets were subjected to analysis of variance (ANOVA) followed by Tukey's test at 5\% significance. The $3 \times 3$ factorial ANOVA was used to compare the average of fish performance and fillet analyzes. The EOcl levels in the diet and the inclusion period before slaughter were considered as factors and when statistical difference was observed, Tukey test $(p<0.05)$ was applied. In addition, contrast analysis was performed comparing the means of the parameters between treatments and control (without inclusion of EOcl during experimental period). The analyses were performed using Statistica 7.0.

\section{Results and discussion}

There was no effect of the levels and period of inclusion of EOcl in the diet on the performance parameters $(p>0.05)$ (Table 2). In addition, there was no interaction effect between these factors or between the treatments of the test diets compared to the control. The final weight and length ranged from $667.81-698.02 \mathrm{~g}$ and $25.68-26.23 \mathrm{~cm}$, respectively. The daily weight gain was between $5.67-6.02 \mathrm{~g}$ and the feed conversion ranged between 1.72 and 1.82 . Fillet yield was above $31 \%$, with $31.72 \%$ being the highest value.

Table 3 shows the antioxidant power of the control and test diets with the inclusion of EOcl. The spaying of EOcl increased the antioxidant power of the diets $(p<0.05)$ and this result could be proven, regardless of the assays used (FRAP, DPPH or ABTS). In addition, as the level of inclusion of EOcl increased, the greater the antioxidant power found.

The assay employing the ABTS radical exhibits affinity in both hydrophilic and lipophilic media, whereas the DPPH and
Table 2. Productive performance of Nile tilapia fed diets containing clove essential oil.

\begin{tabular}{|c|c|c|c|c|c|c|c|c|}
\hline \multirow{2}{*}{ Parameters } & \multirow{2}{*}{ Control $^{1}$} & \multicolumn{3}{|c|}{ Level $(\mathrm{g} / \mathrm{kg})^{2}$} & \multicolumn{3}{|c|}{ Period (days) ${ }^{3}$} & \\
\hline & & 0.70 & 1.05 & 1.40 & 15 & 45 & 60 & \\
\hline & & 667.81 & 691.43 & 698.02 & 696.90 & 74.26 & 686.10 & 8.48 \\
\hline & 8 & 25.68 & 26.09 & 26.23 & 26.04 & 25.89 & 26.07 & 0.14 \\
\hline DV & 6 & 5.67 & 5.95 & 6. & 6.02 & 5.72 & 5.88 & 0.10 \\
\hline $\mathrm{CC}$ & 1.81 & 1.81 & 1.77 & 1.7 & 1.72 & 1.82 & 1.81 & 0.02 \\
\hline $\mathrm{YY}(\%)$ & 31.4 & 31.06 & 31.70 & 31.84 & 31.50 & 31.49 & 31.60 & 0.17 \\
\hline
\end{tabular}

FW = final weight; $\mathrm{FL}=$ final length; $\mathrm{DWG}=$ daily weight gain; $\mathrm{FC}=$ feed conversion; $\mathrm{FY}=$ fillet yield; SEM $=$ Standard error of the mean.${ }^{1} \mathrm{Feed}$ with no essential oils added; ${ }^{2}$ Inclusion level of clove essential oil; ${ }^{3} \mathrm{Clove}$ essential oil inclusion period before slaughter.

Table 3. Antioxidant power of diets.

\begin{tabular}{lccc}
\hline & \multicolumn{3}{c}{ Antioxidant power $(\mu \mathrm{mol}$ TE/g) } \\
\cline { 2 - 4 } & DPPH & FRAP & ABTS \\
\hline Control $^{\dagger}$ & 10.34 & 9.86 & 24.85 \\
Inclusion level of EOcl $(\mathrm{g} / \mathrm{kg})$ & & \\
0.70 & $14.21^{\mathrm{B}^{*}}$ & $14.60^{\mathrm{C}^{*}}$ & $25.10^{\mathrm{C}}$ \\
1.05 & $14.74^{\mathrm{B}^{*}}$ & $16.63^{\mathrm{B}^{*}}$ & $28.00^{\mathrm{B}^{*}}$ \\
1.40 & $16.22^{\mathrm{A}^{*}}$ & $20.38^{\mathrm{A}^{*}}$ & $30.93^{\mathrm{A}^{*}}$ \\
SEM & 0.57 & 0.98 & 0.67 \\
Effect $(p$ value $)$ & $<0.000$ & $<0.000$ & $<0.000$ \\
\hline
\end{tabular}

In the same column, values with different uppercase letters indicate significant difference $(p<0.05)$, while values with ${ }^{*}$ indicate significant difference in relation to the control treatment $(p<0.05) .{ }^{\dagger} \mathrm{Control}$ treatment. $\mathrm{EOcl}=$ clove essential oil; $\mathrm{DPPH}=$ 2,2-difenil-1-picril-hidrazil; FRAP = Ferric reducing ability Power; ABTS = 2,2`'-Azinobis (3-ethylbenzothiazoline-6-sulfonic acid); $\mathrm{SEM}=$ Standard error of the mean.

Table 4. Interactions between level and period of inclusion of clove essential oil in the diet of Nile tilapia on the antioxidant power of fillets.

\begin{tabular}{|c|c|c|c|c|c|}
\hline \multirow[t]{2}{*}{ Level $(\mathrm{g} / \mathrm{kg})^{1}$} & \multicolumn{3}{|c|}{$\begin{array}{l}\text { Period } \\
(\text { days) })^{2}\end{array}$} & \multirow[t]{2}{*}{ Control $^{3}$} & \multirow[t]{2}{*}{ SEM } \\
\hline & 15 & 45 & 60 & & \\
\hline $\mathrm{DPPH}$ & & & & 18.61 & \multirow{4}{*}{0.21} \\
\hline 0.70 & $15.64^{\mathrm{Bb}^{*}}$ & $18.56^{\mathrm{Aa}}$ & $18.66^{\mathrm{Aa}}$ & \multirow{7}{*}{4.65} & \\
\hline 1.05 & $16.44^{\mathrm{Ac}^{*}}$ & $17.60^{\mathrm{Ab}}$ & $18.99^{\mathrm{Aa}}$ & & \\
\hline 1.40 & $16.86^{\mathrm{Aa}^{*}}$ & $15.45^{\mathrm{Bb}^{*}}$ & $16.80^{\mathrm{Ba}^{*}}$ & & \\
\hline FRAP & & & & & \multirow{4}{*}{0.04} \\
\hline 0.70 & $4.55^{\mathrm{B}}$ & $4.74^{\mathrm{AB}}$ & $4.41^{\mathrm{B}}$ & & \\
\hline 1.05 & $5.09^{\mathrm{A}^{*}}$ & $5.04^{\mathrm{A}^{*}}$ & $4.81^{\mathrm{A}}$ & & \\
\hline 1.40 & $4.55^{\mathrm{Bb}}$ & $4.52^{\mathrm{Bb}}$ & $4.95^{\mathrm{Aa}^{*}}$ & & \\
\hline
\end{tabular}

Values with different uppercase letters indicate significant difference $(p<0.05)$ in the column, while, values with different lowercase letters indicate significant difference $(p<0.05)$ in the row. Values with * indicate significant difference in relation to the control treatment $(p<0.05)$. DPPH $=2$ 2,-difenil-1-picril-hidrazil; FRAP $=$ Ferric reducing ability Power; SEM = Standard error of the mean. ${ }^{1}$ Inclusion level of clove essential oil; ${ }^{2} \mathrm{Clove}$ essential oil inclusion period (days) before slaughter; ${ }^{3} \mathrm{Feed}$ with nwo essential oils added.

FRAP assays act only in hydrophilic media (Serpen et al., 2012), which explains the differences in values between the assays. The EOcl and its main compound, eugenol, are lipophilic (Raut \& Karuppayil, 2014; Kumar et al., 2015; Prakash et al., 2015; Yadav et al., 2015); therefore, the ABTS assay resulted in the highest antioxidant power values in the diets and fillets.

Interaction between period and level of inclusion of EOcl in the antioxidant power of the fillets and the contrast analysis between test diets and the control diet was verified in the DPPH and FRAP assays $(p<0.05)$ (Table 4$)$. In the FRAP assay, it was verified that 
the inclusion of $1.05 \mathrm{~g} / \mathrm{kg}$ of EOcl in the fish diet for 15 days before slaughter, resulted in fillets with greater antioxidant power when compared to the control. When considering only the test diets, the highest values of fillet antioxidant power were also found for EOcl level of $1.05 \mathrm{~g} / \mathrm{kg}$, regardless of the period and assays.

Some dietary antioxidants perform functions that contribute to animal growth or protection against oxidation generated by stress during cultivation, and no significant increase occurs in the fillets' antioxidant power after antioxidant deposition in the musculature (Carbonera et al., 2014b, 2016). This may explain the results obtained in the present study, where the antioxidant power of fish fillets that received diets with or without the inclusion of EOcl did not differ statistically. The antioxidant power of the diet may have contributed to the control of oxidative stress caused by environmental, biological and management-related factors.

The gene expression of the catalase, glutathione peroxidase and glutathione synthetase in Nile tilapia muscle are show in Table 5. The level and period of inclusion of EOcl in the fosh diet did not influence the gene expression of these enzymes $(p>0.05)$. However, the gene expression of CAT and GSS was lower in the muscle of fish that received diets containing EOcl when compared to those that received the control diet $(p<0.05)$.

The enzymes evaluated in the present study act through preventive mechanisms and prevent and/or control the formation of reactive oxygen species (ROS) (Lee et al., 2004). The antioxidant action of essential oils is attributed to phenolic compounds that make ROS free radicals chain reactions null by donating hydrogens and electrons (Shahidi et al., 1992). The lowest gene expression of CAT and GSS enzymes in the muscle of fish that received diets containing EOcl, regardless of the level or period, indicates that their phenolic compounds are acting as antioxidant agents and contributing to control the oxidation process.

The lipid oxidation was influenced by the interaction between the levels and period of inclusion of EOcl in the fish diet $(p<0.05)$ (Table 6). The reduction in lipid oxidation in the fillets with the EOcl ranged from 2.8 to $43.3 \%$ relative to the control group. On day 7 , lipid oxidation was significantly reduced relative to the control group, except the interaction of 1.40/15. On days 1 and 14 , some interactions had pro-oxidant effects; however, MDA values did not differ $(p>0.05)$ from those of the control group.

Lipid oxidation can occur before, during and after animal slaughter. Saturated and unsaturated fatty acids deteriorating by an autocatalytic mechanism involving free radical presence or any other condition favorable to oxidation, leading to product depreciation (Yadav et al., 2015).

The antioxidant power results suggest that EOcl provides a source of antioxidants that control lipid oxidation in the fillets. The antioxidant effect of clove essential oil is mainly attributed to its major compound, eugenol (Biondo et al., 2017). This compound includes a hydroxyl $(\mathrm{OH})$ group and an aromatic ring in its structure, allowing the transfer or donation of electrons and/or protons to the radical while remaining stable due to the resonance effect (Amorati et al., 2013; Kumar et al., 2015).

Synergism between the compounds in EOcl, especially between minority compounds with variable activity, is a positive
Table 5. Gene expression of enzymes in the muscle of Nile tilapia fed diets containing clove essential oil.

\begin{tabular}{|c|c|c|c|c|c|c|c|c|}
\hline \multirow{2}{*}{ Enzymes } & \multirow{2}{*}{ Control $^{1}$} & \multicolumn{3}{|c|}{ Level $(\mathrm{g} / \mathrm{kg})^{2}$} & \multicolumn{3}{|c|}{ Period (days) ${ }^{3}$} & \multirow{2}{*}{ SEM } \\
\hline & & 0.70 & 1.05 & 1.40 & 15 & 45 & 60 & \\
\hline $\begin{array}{l}\text { CAT } \\
\text { (UA) }\end{array}$ & $0.281^{\star}$ & $0.050^{*}$ & $0.020^{*}$ & $0.036^{*}$ & $0.043^{*}$ & $0.036^{*}$ & $0.026^{\star}$ & 0.02 \\
\hline $\begin{array}{l}\text { GPX } \\
\text { (UA) }\end{array}$ & 0.076 & 0.305 & 0.285 & 0.235 & 0.322 & 0.344 & 0.160 & 0.04 \\
\hline $\begin{array}{l}\text { GSS } \\
\text { (UA) }\end{array}$ & $0.881^{\star}$ & $0.031^{\star}$ & $0.032^{*}$ & $0.036^{*}$ & $0.053^{*}$ & $0.033^{*}$ & $0.013^{\star}$ & 0.05 \\
\hline
\end{tabular}

Values with ${ }^{*}$ indicate significant difference in relation to the control treatment $(p<0.05)$. $\mathrm{CAT}=$ Catalase; $\mathrm{GPX}=$ Glutathione peroxidase; $\mathrm{GSS}=$ Glutathione synthetase; $\mathrm{SEM}=$ Standard error of the mean. ${ }^{1}$ Feed with no essential oils added; ${ }^{2}$ Inclusion level of clove essential oil; ${ }^{3} \mathrm{Clove}$ essential oil inclusion period before slaughter.

Table 6. Interactions between level and period of inclusion of clove essential oil in the diet of Nile tilapia on lipid oxidation ( $\mathrm{mg}$ malonaldehyde $/ \mathrm{kg}$ ) in fillets stored in a refrigerated display at $4{ }^{\circ} \mathrm{C}$ for 14 days.

\begin{tabular}{|c|c|c|c|c|c|c|}
\hline \multirow{2}{*}{$\begin{array}{c}\text { Evaluation } \\
\text { period }\end{array}$} & \multirow{2}{*}{$\begin{array}{c}\text { Level } \\
(\mathrm{g} / \mathrm{kg})^{1}\end{array}$} & \multicolumn{3}{|c|}{ Period (days) $^{2}$} & \multirow{2}{*}{ Control $^{3}$} & \multirow{2}{*}{ SEM } \\
\hline & & 15 & 45 & 60 & & \\
\hline \multirow[t]{4}{*}{ Day 1} & & & & & 0.030 & \multirow{4}{*}{0.001} \\
\hline & 0.70 & 0.032 & $0.031^{\mathrm{AB}}$ & 0.026 & & \\
\hline & 1.05 & 0.034 & $0.032^{\mathrm{B}}$ & 0.032 & & \\
\hline & 1.40 & $0.031^{\mathrm{ab}}$ & $0.023^{\mathrm{Aa}}$ & $0.032^{\mathrm{b}}$ & & \\
\hline \multirow[t]{4}{*}{ Day 7} & & & & & 0.106 & \multirow{4}{*}{0.003} \\
\hline & 0.70 & $0.063^{\mathrm{A}^{*}}$ & $0.062^{\star}$ & $0.061^{\star}$ & & \\
\hline & 1.05 & $0.066^{\mathrm{A}^{*}}$ & $0.069^{\star}$ & $0.059^{\star}$ & & \\
\hline & 1.40 & $0.093^{\mathrm{Bb}}$ & $0.067^{\mathrm{a}^{*}}$ & $0.072^{\mathrm{a}^{*}}$ & & \\
\hline \multirow[t]{4}{*}{ Day 14} & & & & & 0.173 & \multirow{4}{*}{0.005} \\
\hline & 0.70 & $0.123^{\mathrm{a}^{*}}$ & $0.199^{\mathrm{Bb}}$ & $0.116^{\mathrm{Aa}^{*}}$ & & \\
\hline & 1.05 & $0.134^{*}$ & $0.168^{\mathrm{A}}$ & $0.152^{\mathrm{B}}$ & & \\
\hline & 1.40 & $0.105^{\mathrm{a}^{*}}$ & $0.148^{\mathrm{Ab}}$ & $0.117^{\mathrm{ABab}^{*}}$ & & \\
\hline
\end{tabular}

Values with different uppercase letters indicate significant difference $(p<0.05)$ in the column, while values with different lowercase letters indicate significant difference $(p<0.05)$ in the row. Values with ${ }^{*}$ indicate significant difference in relation to the control treatment $(p<0.05)$. SEM $=$ Standard error of the mean. ${ }^{1}$ Inclusion level of clove essential oil; ${ }^{2}$ Clove essential oil inclusion period before slaughter; ${ }^{3}$ Feed with no essential oils added.

feature (Burt, 2004). Antioxidant effects in essential oils are generally related to the dose in the food and the concentration of molecules with antioxidant activity. Likewise, inadequate doses of essential oils in the food can cause undesirable effects (Burt, 2004; Carocho et al., 2014, 2015) with reduced nutritional (pro-oxidant effect) and sensorial (aroma and flavor) fillet quality (Raeisi et al., 2015; Van Haute et al., 2016).

Clove essential oil pro-oxidant effect was observed on day 1; however, the MDA variation did not differ from that of the control group. This effect is related to the auto-oxidation of the antioxidants in high concentrations (Shahidi \& Zhong, 2010). In essential oils, this effect is also attributed to cytotoxic effects, triggering a state of oxidative stress (Bakkali et al., 2008)

There was no significant effect of the level and period of inclusion of EOcl in the diet on the parameter of texture, $\mathrm{pH}$ and color of the fillets $(p>0.05)$ (Table 7). Likewise, there was no interaction effect between these factors $(p>0.05)$. When comparing the averages of the test diets in relation to the control, only a significant difference was found for the texture 
Table 7. Physical, chemical, and sensory characteristics of Nile tilapia fillets fed diets containing clove essential oil.

\begin{tabular}{|c|c|c|c|c|c|c|c|c|c|}
\hline & & \multirow{2}{*}{ Control $^{1}$} & \multicolumn{3}{|c|}{ Level $(\mathrm{g} / \mathrm{kg})^{2}$} & \multicolumn{3}{|c|}{ Period (days) ${ }^{3}$} & \multirow{2}{*}{ SEM } \\
\hline & & & 0.70 & 1.05 & 1.40 & 15 & 45 & 60 & \\
\hline Texture (N) & & 3.37 & $4.43^{*}$ & $4.36^{*}$ & $4.49^{*}$ & $4.53^{*}$ & $4.37^{*}$ & $4.39^{\star}$ & 0.08 \\
\hline $\mathrm{pH}$ & & 6.00 & 6.11 & 6.03 & 6.07 & 6.05 & 6.04 & 6.07 & 0.01 \\
\hline \multirow[t]{3}{*}{ Color } & $\mathrm{L}^{*}$ & 49.31 & 48.49 & 49.97 & 49.61 & 49.59 & 49.36 & 49.11 & 0.30 \\
\hline & $a^{*}$ & -3.08 & -3.27 & -3.45 & -3.45 & -3.38 & -3.44 & -3.35 & 0.06 \\
\hline & $p^{*}$ & 1.72 & 1.38 & 1.41 & 1.06 & 1.48 & 1.52 & 0.84 & 0.21 \\
\hline Aroma & & 6.77 & 6.91 & 6.92 & 6.8 & 6.88 & 6.86 & 6.90 & 0.05 \\
\hline Texture & & 7.24 & 7.36 & 7.33 & 7.28 & 7.20 & 7.42 & 7.35 & 0.04 \\
\hline Flavor & & 6.89 & 7.13 & 7.03 & 7.05 & 7.02 & 7.06 & 7.05 & 0.05 \\
\hline $\begin{array}{l}\text { General } \\
\text { acceptance }\end{array}$ & & 93 & 7.18 & 7.12 & 00 & .04 & 7.16 & 7.10 & 0.05 \\
\hline
\end{tabular}

Values with ${ }^{*}$ indicate significant difference in relation to the control treatment $(p<0.05)$. $\mathrm{SEM}=$ Standard error of the mean. ${ }^{1}$ Feed with no essential oils added $;{ }^{2}$ Inclusion level of clove essential oil; ${ }^{3}$ Clove essential oil inclusion period before slaughter.

$(p<0.05)$ (Table 7$)$. The highest values of this parameter were for fish fillets that received diets containing EOcl, regardless of the supply period.

The loss of firmness begins post slaughter and progresses during storage, mainly via degradation of connective tissue proteins (Ahmed et al., 2015). Texture is an important sensory parameter, and firmer fillets present better acceptability (Bahuaud et al., 2010a). Microbial activity, autolysis (Shouchun et al., 2010; Cai et al., 2015) and preslaughter stress with reduced water retention capacity (Goes et al., 2015) are factors that contribute to reduced fillet firmness.

The benefit of EOcl in the texture of the fillets may be related to its antimicrobial property (Solórzano-Santos \& MirandaNovales, 2012) and the maintenance of the integrity of the cell membranes. Fillet texture is affected by cathepsins and calpains, which reduce cell integrity, leading to the release of proteases and muscle degradation (Bahuaud et al., 2010b; Kemp et al., 2010; Ahmed et al., 2015). Lipophilic antioxidants exhibit increased interactions with the lipoprotein membrane and accumulate in the cells, affecting their integrity (Roleira et al., 2010). Therefore, the compounds present in EOcl may have contributed to cell membrane integrity, thus reducing intracellular content losses.

$\mathrm{pH}$ is frequently used to determine fish freshness and is related to animal management prior to slaughter. In less stressed animals, muscle $\mathrm{pH}$ is higher than that in stressed animals, with a marked drop after slaughter (Goes et al., 2015). Under adequate conditions, the $\mathrm{pH}$ should decrease gradually, remaining near 6.0, then increasing with the onset of deterioration due to autolysis and microbial activity.

Fillet color is considered an important attribute by consumers for species such as salmon and trout, but less important for white-flesh species such as Nile tilapia. Pigments present in the diets and deposited into the fillets were studied for corn-based coproducts, with no significant color changes (Herath et al., 2016). Pigment presence in the EOs is small and does not detract from the fillets' color. No differences were observed in gilthead bream fillets fed diets supplemented with thyme essential oil (Hernández et al., 2015).
Studies that directly applied EO onto fillets by including it in edible coatings (Raeisi et al., 2015) or marinades (Van Haute et al., 2016) described a positive effect on controlling lipid oxidation. However, in the sensory evaluation, scores for the evaluated attributes were inferior to those of the control treatment. The authors attributed this result to the characteristic aroma of the essential oils. This problem was not observed in the present study after including EOcl in the animal diets and corroborates the results of Hernández et al. (2015) when evaluating the inclusion of thyme essential oil in gilthead seabream diets.

\section{Conclusion}

The inclusion of up to $1.40 \mathrm{~g} / \mathrm{kg}$ of clove essential oil on the Nile tilapia diet does not affect the fish performance. Considering the interactions, including $1.05 \mathrm{~g} / \mathrm{kg}$ of EOcl in the diets for 15 days before slaughter increases the antioxidant power, reduces lipid oxidation, and does not influence the sensory characteristics of Nile tilapia fillets.

\section{Acknowledgements}

The author are grateful to the State University of Maringá for the donation of fish and the structure for carrying out the experiment and analysis. This was supported by National Council for Scientific and Technological Development (CNPq).

\section{References}

Ahmed, Z., Donkor, O., Street, W. A., \& Vasiljevic, T. (2015). Calpainsand cathepsins-induced myofibrillar changes in post-mortem fish: Impact on structural softening and release of bioactive peptides. Trends in Food Science \& Technology, 45(1), 130-146. http://dx.doi. org/10.1016/j.tifs.2015.04.002.

Amorati, R., Foti, M. C., \& Valgimigli, L. (2013). Antioxidant activity of essential oils. Journal of Agricultural and Food Chemistry, 61 (46), 10835-10847. http://dx.doi.org/10.1021/jf403496k. PMid:24156356.

Bahuaud, D., Gaarder, M., Veiseth-Kent, E., \& Thomassen, M. (2010a). Fillet texture and protease activities in different families of farmed Atlantic salmon (Salmo salar L.). Aquaculture, 310(1-2), 213-220. http://dx.doi.org/10.1016/j.aquaculture.2010.10.008.

Bahuaud, D., Mørkøre, T., Østbye, T.-K., Veiseth-Kent, E., Thomassen, M. S., \& Ofstad, R. (2010b). Muscle structure responses and lysosomal cathepsins B and $\mathrm{L}$ in farmed Atlantic salmon (Salmo salar L.) pre- and post-rigor fillets exposed to short and long-term crowding stress. Food Chemistry, 118(3), 602-615. http://dx.doi. org/10.1016/j.foodchem.2009.05.028.

Bakkali, F., Averbeck, S., Averbeck, D., \& Idaomar, M. (2008). Biological effects of essential oils: a review. Food and Chemical Toxicology, 46(2), 446-475. http://dx.doi.org/10.1016/j.fct.2007.09.106. PMid:17996351.

Bernardi, D. M., Bertol, T. M., Pflanzer, S. B., Sgarbieri, V. C., \& Pollonio, M. A. R. (2016). $\omega-3$ in meat products: benefits and effects on lipid oxidative stability. Journal of the Science of Food and Agriculture, 96(8), 2620-2634. http://dx.doi.org/10.1002/jsfa.7559. PMid:26676414.

Biondo, P. B. F., Carbonera, F., Zawadzki, F., Chiavelli, L. U. R., Pilau, E. J., Prado, I. N., \& Visentainer, J. (2017). Antioxidant capacity and identification of bioactive compounds by GC-MS of essential oils from spices, herbs and citrus. Current Bioactive Compounds, 13(2), 137-143. http://dx.doi.org/10.2174/1573407212666160614080846. 
Burt, S. (2004). Essential oils: their antibacterial properties and potential applications in foods-a review. International Journal of Food Microbiology, 94(3), 223-253. http://dx.doi.org/10.1016/j. ijfoodmicro.2004.03.022. PMid:15246235.

Cai, L., Cao, A., Li, Y., Song, Z., Leng, L., \& Li, J. (2015). The effects of essential oil treatment on the biogenic amines inhibition and quality preservation of red drum (Sciaenops ocellatus) fillets. Food Control, 56, 1-8. http://dx.doi.org/10.1016/j.foodcont.2015.03.009.

Carbonera, F., Bonafe, E. G., Martin, C. A., Montanher, P. F., Ribeiro, R. P., Figueiredo, L. C., Almeida, V. C., \& Visentainer, J. V. (2014a). Effect of dietary replacement of sunflower oil with perilla oil on the absolute fatty acid composition in Nile tilapia (GIFT). Food Chemistry, 148, 230-234. http://dx.doi.org/10.1016/j.foodchem.2013.10.038. PMid:24262550.

Carbonera, F., Montanher, P. F., Figueiredo, I. L., Bonafé, E. G., Santos Júnior, O. O., Sargi, S. C., Gonçalves, R. M., Matsushita, M., \& Visentainer, J. V. (2016). Lipid composition and antioxidant capacity evaluation in tilapia fillets supplemented with a blend of oils and vitamin E. Journal of the American Oil Chemists' Society, 93(9), 1255-1264. http://dx.doi.org/10.1007/s11746-016-2869-7.

Carbonera, F., Montanher, P. F., Palombini, S. V., Maruyama, S. A., Claus, T., Santos, H. M. C., Sargi, S. C., Matsushita, M., \& Visentainer, J. V. (2014b). Antioxidant capacity in tilapia fillets enriched with extract of acerola fruit residue. Journal of the Brazilian Chemical Society, 25, 1237-1245. http://dx.doi.org/10.5935/0103-5053.20140101.

Carocho, M., Barreiro, M. F., Morales, P., \& Ferreira, I. C. F. R. (2014). Adding molecules to food, pros and cons: a review on synthetic and natural food additives. Comprehensive Reviews in Food Science and Food Safety, 13(4), 377-399. http://dx.doi.org/10.1111/15414337.12065. PMid:33412697.

Carocho, M., Morales, P., \& Ferreira, I. C. F. R. (2015). Natural food additives: quo vadis? Trends in Food Science \& Technology, 45(2), 284-295. http://dx.doi.org/10.1016/j.tifs.2015.06.007.

Fasseas, M. K., Mountzouris, K. C., Tarantilis, P. A., Polissiou, M., \& Zervas, G. (2008). Antioxidant activity in meat treated with oregano and sage essential oils. Food Chemistry, 106(3), 1188-1194. http:// dx.doi.org/10.1016/j.foodchem.2007.07.060

Font I Furnols, M., Gispert, M., Guerrero, L., Velarde, A., Tibau, J., Soler, J., Hortós, M., García-Regueiro, J. A., Pérez, J., Suárez, P., \& Oliver, M. A. (2008). Consumers' sensory acceptability of pork from immunocastrated male pigs. Meat Science, 80(4), 1013-1018. http://dx.doi.org/10.1016/j.meatsci.2008.04.018. PMid:22063830.

Food and Agriculture Organization - FAO. (2020). The state of world fisheries and aquaculture. Rome: FAO.

Goes, E. S. R., Lara, J. A. F., Gasparino, E., Del Vesco, A. P., Goes, M. D., Alexandre Filho, L., \& Ribeiro, R. P. (2015). Pre-slaughter stress affects ryanodine receptor protein gene expression and the water-holding capacity in fillets of the Nile tilapia. PLoS One, 10(6), e0129145. http://dx.doi.org/10.1371/journal.pone.0129145. PMid:26053858.

Herath, S. S., Haga, Y., \& Satoh, S. (2016). Effects of long-term feeding of corn co-product-based diets on growth, fillet color, and fatty acid and amino acid composition of Nile tilapia, Oreochromis niloticus. Aquaculture, 464, 205-212. http://dx.doi.org/10.1016/j. aquaculture.2016.06.032.

Hernández, A., García García, B., Jordán, M. J., \& Hernández, M. D. (2015). Study of the dose of thyme essential oil in feed to prolong the shelf life of gilthead seabream (Sparus aurata). Aquaculture Nutrition, 21(5), 740-749. http://dx.doi.org/10.1111/anu.12196.

Integrated DNA Technologies - IDT. (2021). Retrieved from https:// www.idtdna.com.
Jiang, J., \& Xiong, Y. L. (2016). Natural antioxidants as food and feed additives to promote health benefits and quality of meat products: a review. Meat Science, 120, 107-117. http://dx.doi.org/10.1016/j. meatsci.2016.04.005. PMid:27091079.

Kemp, C. M., Sensky, P. L., Bardsley, R. G., Buttery, P. J., \& Parr, T. (2010). Tenderness: an enzymatic view. Meat Science, 84(2), 248-256. http://dx.doi.org/10.1016/j.meatsci.2009.06.008. PMid:20374783.

Kumar, Y., Yadav, D. N., Ahmad, T., \& Narsaiah, K. (2015). Recent trends in the use of natural antioxidants for meat and meat products. Comprehensive Reviews in Food Science and Food Safety, 14(6), 796812. http://dx.doi.org/10.1111/1541-4337.12156.

Lee, J., Koo, N., \& Min, D. B. (2004). Reactive oxygen species, aging, and antioxidative nutraceuticals. Comprehensive Reviews in Food Science and Food Safety, 3(1), 21-33. http://dx.doi.org/10.1111/j.1541-4337.2004. tb00058.x. PMid:33430557.

Montanher, P. F., Costa e Silva, B., Bonafé, E. G., Carbonera, F., dos Santos, H. M. C., de Lima Figueiredo, I., Maruyama, S. A., Matsushita, M., \& Visentainer, J. V. (2016). Effects of diet supplementation with chia (Salvia hispanica L.) oil and natural antioxidant extract on the omega-3 content and antioxidant capacity of Nile tilapia fillets. European Journal of Lipid Science and Technology, 118(5), 698-707. http://dx.doi.org/10.1002/ejlt.201400334.

National Center for Biotechnology Information - NCBI. (2021). Retrieved from https://www.ncbi.nlm.nih.gov/.

Oskoueian, E., Maroufyan, E., Goh, Y. M., Ramezani-Fard, E., \& Ebrahimi, M. (2013). Clove essential oil improves lipid peroxidation and antioxidant activity in tilapia fish fillet cooked by grilling and microwaving. International Journal of Biological, Biomolecular, Agriculturar. Food and Biotechnological Engineering, 7(12), 1176-1178.

Prakash, B., Kedia, A., Mishra, P. K., \& Dubey, N. K. (2015). Plant essential oils as food preservatives to control moulds, mycotoxin contamination and oxidative deterioration of agri-food commodities: potentials and challenges. Food Control, 47, 381-391. http://dx.doi. org/10.1016/j.foodcont.2014.07.023.

Raeisi, M., Tajik, H., Aliakbarlu, J., Mirhosseini, S. H., \& Hosseini, S. M. H. (2015). Effect of carboxymethyl cellulose-based coatings incorporated with Zataria multiflora Boiss. essential oil and grape seed extract on the shelf life of rainbow trout fillets. LebensmittelWissenschaft + Technologie, 64(2), 898-904. http://dx.doi.org/10.1016/j. lwt.2015.06.010.

Rapoport, S. I., Ramadan, E., \& Basselin, M. (2011). Docosahexaenoic acid (DHA) incorporation into the brain from plasma, as an in vivo biomarker of brain DHA metabolism and neurotransmission. Prostaglandins \& Other Lipid Mediators, 96(1-4), 109-113. http:// dx.doi.org/10.1016/j.prostaglandins.2011.06.003. PMid:21704722.

Raut, J. S., \& Karuppayil, S. M. (2014). A status review on the medicinal properties of essential oils. Industrial Crops and Products, 62, 250264. http://dx.doi.org/10.1016/j.indcrop.2014.05.055.

Roleira, F. M. F., Siquet, C., Orrù, E., Garrido, E. M., Garrido, J., Milhazes, N., Podda, G., Paiva-Martins, F., Reis, S., Carvalho, R. A., Silva, E. J. T., \& Borges, F. (2010). Lipophilic phenolic antioxidants: correlation between antioxidant profile, partition coefficients and redox properties. Bioorganic \& Medicinal Chemistry, 18(16), 58165825. http://dx.doi.org/10.1016/j.bmc.2010.06.090. PMid:20650639.

Serpen, A., Gökmen, V., \& Fogliano, V. (2012). Total antioxidant capacities of raw and cooked meats. Meat Science, 90(1), 60-65. http://dx.doi.org/10.1016/j.meatsci.2011.05.027. PMid:21684086.

Shahidi, F., \& Zhong, Y. (2010). Lipid oxidation and improving the oxidative stability. Chemical Society Reviews, 39(11), 4067-4079. http://dx.doi.org/10.1039/b922183m. PMid:20617249. 
Shahidi, F., Janitha, P. K., \& Wanasundara, P. D. (1992). Phenolic antioxidants. Critical Reviews in Food Science and Nutrition, 32(1), 67-103. http://dx.doi.org/10.1080/10408399209527581. PMid:1290586.

Shouchun, L., Wen, F., Saiyi, Z., Changwei, M., Pinglan, L., Kang, Z., Zhaohui, P., \& Meijun, Z. (2010). Quality evaluation of traypacked tilapia fillets stored at $0 \mathrm{C}$ based on sensory, microbiological, biochemical and physical attributes. African Journal of Biotechnology, 9(5), 692-701. http://dx.doi.org/10.5897/AJB09.1369.

Solórzano-Santos, F., \& Miranda-Novales, M. G. (2012). Essential oils from aromatic herbs as antimicrobial agents. Current Opinion in Biotechnology, 23(2), 136-141. http://dx.doi.org/10.1016/j. copbio.2011.08.005. PMid:21903378.

Van Haute, S., Raes, K., Van der Meeren, P., \& Sampers, I. (2016). The effect of cinnamon, oregano and thyme essential oils in marinade on the microbial shelf life of fish and meat products. Food Control, 68, 30-39. http://dx.doi.org/10.1016/j.foodcont.2016.03.025.

Vieira, S. A., Zhang, G., \& Decker, E. A. (2017). Biological implications of lipid oxidation products. Journal of the American Oil Chemists' Society, 94(3), 339-351. http://dx.doi.org/10.1007/s11746-017-2958-2.
Visentainer, J. V., de Souza, N. E., Makoto, M., Hayashi, C., \& Franco, M. R. B. (2005). Inlfuence of diets enriched with flaxseed oil on the a-linolenic, eicosapentaenoic and docosahexaenoic fatty acid in Nile tilapia (Oreochromis niloticus). Food Chemistry, 90(4), 557-560. http://dx.doi.org/10.1016/j.foodchem.2004.05.016.

Vyncke, W. (1970). Direct determination of the thiobarbituric acid value in trichloracetic acid extracts of fish as a measure of oxidative rancidity. Fette Seifen Anstrichmittel, 72(12), 1084-1087. http:// dx.doi.org/10.1002/lipi.19700721218.

Yadav, M. K., Chae, S.-W., Im, G. J., Chung, J.-W., \& Song, J.-J. (2015). Eugenol: a phyto-compound effective against methicillin-resistant and methicillin-sensitive Staphylococcus aureus clinical strain biofilms. PLoS One, 10(3), e0119564. http://dx.doi.org/10.1371/ journal.pone.0119564. PMid:25781975.

Yang, C. G., Wang, X. L., Tian, J., Liu, W., Wu, F., Jiang, M., \& Wen, H. (2013). Evaluation of reference genes for quantitative real-time RT-PCR analysis of gene expression in Nile tilapia (Oreochromis niloticus). Gene, 527(1), 183-192. http://dx.doi.org/10.1016/j. gene.2013.06.013. PMid:23792389. 